\title{
PENGARUH KUALITAS PELAYANAN TERHADAP KEPUASAN PESERTA PENSIUN PADA PT. TASPEN (PERSERO) CABANG DEPOK
}

\author{
${ }^{1)}$ Benny Osta Nababan, ${ }^{2)}$ Tanisa Adra Oktaviani \\ ${ }^{1)}$ Dosen Program Studi Manajemen, STIE Dewantara \\ J1. Raya Pemda Bojong Depok Baru III, Karadenan, Cibinong, Bogor, Jawa Barat 16913, Indonesia \\ Email: benny.osta@dewantara.ac.id \\ ${ }^{2)}$ Alumni Program Studi Manajemen, STIE Dewantara \\ Jl. Raya PemdaBojong Depok Baru III, Karadenan, Cibinong, Bogor, Jawa Barat 16913,Indonesia \\ Email: tanisaadra@yahoo.co.id
}

\begin{abstract}
This study aims to analyze the factors that affect the satisfaction of participants Pension $(Y)$ at PT.Taspen (Persero) Branch Depok. Independent variables used in this research are Tangible (XI), Reliability (X2), Responsiveness (X3), Assurance (X4) and Emphaty (X5). The sample of this research is 100 Participants from all population. Data collection techniques in this study using questionnaires and literature study. Data analysis technique using multiple linear regression analysis with SPSS program. The results showed that tangible $(X 1)$, reliability $(X 2)$, and responsiveness $(X 3)$ partially have a significant influence on satisfaction of pension participant $(Y)$ meaning that the better tangible, reliability and responsiveness then the satisfaction of pension participant will increase. Assurance (X4) and Emphaty (X5) are not partially insignificant to the satisfaction of the Pension Participant $(Y)$. The result of calculation of coefficient of determination shows that the satisfaction of the participant of pension is influenced by five independent variables such as tangible (X1), reliability (X2), responsiveness (X3), assurance (X4) and Emphaty (X5) equal to 53,7\% and the rest equal to 46, $3 \%$ is influenced by other factors.
\end{abstract}

Keywords: Quality of Service (Tangible, Reliability, Responsiveness, Assurance, Emphaty) and Satisfaction of Pension Participants.

\begin{abstract}
ABSTRAK
Penelitian ini bertujuan untuk menganalisis faktor-faktor yang mempengaruhi Kepuasan peserta Pensiun (Y) Pada PT.Taspen (Persero) Cabang Depok. Variabel independen yang digunakan dalam penelitian ini antara lain Tangible $\left(\mathrm{X}_{1}\right)$, Reliability $\left(\mathrm{X}_{2}\right)$, Responsiveness $\left(\mathrm{X}_{3}\right)$, Assurance $\left(\mathrm{X}_{4}\right)$ dan Emphaty $\left(\mathrm{X}_{5}\right)$. Sampel Penelitian ini sebanyak 100 Peserta Pensiun dari seluruh jumlah populasi. Teknik pengumpulan data dalam penelitian ini menggunakan kuesioner dan studi pustaka. Teknik analisa data menggunakan analisis regresi linier berganda dengan bantuan program SPSS. Hasil Penelitian menunjukkan bahwa tangible $\left(\mathrm{X}_{1}\right)$, reliability $\left(\mathrm{X}_{2}\right)$, dan responsiveness $\left(\mathrm{X}_{3}\right)$ secara parsial memiliki pengaruh yang signifikan terhadap kepuasan peserta pensiun $(\mathrm{Y})$ artinya semakin baik tangible, reliability dan responsiveness maka kepuasan peserta pensiun akan semakin meningkat. Assurance $\left(\mathrm{X}_{4}\right)$ dan Emphaty $\left(\mathrm{X}_{5}\right)$ secara parsial tidak berpengaruh dan tidak signifikan terhadap kepuasan Peserta Pensiun (Y). Hasil dari perhitungan koefisien determinasi meunjukan bahwa kepuasan peserta pensiun dipengaruhi kelima variabel independen antara lain tangible $\left(\mathrm{X}_{1}\right)$, reliability $\left(\mathrm{X}_{2}\right)$, responsiveness $\left(\mathrm{X}_{3}\right)$, assurance $\left(\mathrm{X}_{4}\right)$ dan Emphaty $\left(\mathrm{X}_{5}\right)$ sebesar $53,7 \%$ dan sisanya sebesar $46,3 \%$ dipengaruhi oleh faktor-faktor lainnya.
\end{abstract}

Kata kunci: Kualitas Pelayanan (Tangible, Reliability, Responsiveness, Assurance, Emphaty) dan Kepuasan Peserta Pensiun.

\begin{tabular}{ll}
\hline 1. PENDAHULUAN & terlepas dari unsur layanan, baik itu jasa \\
1.1 Latar Belakang & sebagai produk inti, maupun sebagai produk \\
Era globalisasi ini persaingan bisnis & pelengkap. Oleh karena itu, perhatian terhadap \\
menjadi sangat tajam, baik di pasar domestik & kepuasan pelanggan semakin besar dan \\
(nasional) maupun di pasar international atau & ditingatkan lagi untuk memenangkan \\
global. Produk apapun yang dihasilkan tidak & persaingan, perusahaan harus mampu
\end{tabular}


memberikan kepuasan kepada para pelangganya.

Kepuasan konsumen adalah sejauh mana suatu tingkatan produk di persepsikan sesuai dengan harapan pembeli (Kotler dalam Sangadji \& Sopiah, 2013:181). Kepuasan konsumen merupakan tingkat perasaan seseorang setelah membandingkan kinerja atau hasil yang dirasakan kemudian dibandingkan dengan harapan. Tingkat kepuasan pelanggan sangat tergantung pada mutu suatu produk atau jasa. Pengukuran kepuasan pelanggan merupakan elemen penting dalam menyediakan pelayanan yang lebih baik, lebih efisien dan lebih efektif. Oleh karena itu hampir setiap perusahaan saat ini menyadari penting arti pelanggan bagi perusahaan dan berupaya keras untuk dapat memberikan kepuasan kepada pelanggan.

Dalam memberikan pelayanan, setidaknya perusahaan harus memenuhi 5 dimensi kualitas jasa yang disebut RATER sehingga dapat menciptakan peserta/pelanggan yang loyal, yaitu reabillity (reliability), assurance (assurance), tangible (tangible), empathy (komunikasi) dan responsiveness (cepat tanggap). (Parasuraman dalam Sangadji \& Sopiah, 2013:100).

Kunci untuk memberikan kualitas pelayanan yang lebih baik adalah memenuhi atau melebihi ekspektasi kualitas pelayanan pelanggan sasaran. Kualitas memiliki hubungan yang erat dengan kepuasan pelanggan, kualitas memberikan suatu dorongan kepada pelanggan untuk menjalin ikatan yang kuat dengan pelanggan. (Tjiptono dalam Sangadji\& Sopiah, 2013:100) menjelaskan Apabila jasa yang diterima atau disarankan sesuai dengan yang diharapkan, kualitas jasa dipersepsikan baik dan memuaskan. Jika jasa yang diterima melampaui harapan pelanggan, kualitas jasa dipersepsikan sebagai kualitas yang ideal. Sebaliknya, apabila jasa yang diterima lebih rendah dari pada yang diharapkan, kualitas jasa dipersepsikan buruk.

PT TASPEN (Persero) Cabang Depok adalah Badan Usaha Milik Negara (BUMN)
Kantor Cabang Depok berawal dari kantor cabang pembantu sejak akhir tahun 2010 dengan mendasari surat keputusan Direksi Nomor : SK-38/DIR/2010 dan resmi menjadi Kantor Cabang sejak bulan september 2013 dengan mendasari Peraturan Direksi Nomor : PD-20/DIR/2013 tanggal 04 september 2013. Dengan membawahi satu wilayah kota Depok. PT Taspen (Persero) Cabang Depok berlokasikan di Jl. Raya Kalimulya No.99 Kel. Kalimulya Kec. Cilodong Kota Depok dengan jumlah peserta aktif sebanyak 7.715 dan peserta pensiun 23.258.

Produk-produk PT. Taspen (Persero) Cabang Depok yang sebagian besar merupakan produk asuransi diantaranya Tabungan Hari Tua (THT), Pensiun, Assurance Kecelakaan Kerja (JKK) dan Assurance Kematian (JKM). PT. Taspen (Persero) Cabang Depok merupakan sebuah perusahaan jasa yang sedang berkembang sehingga memerlukan langkah-langkah guna meningkatkan kepuasan pesertanya. Berdasarkan latar belakang masalah tersebut maka perlu untuk melakukan penelitian mengenai "Pengaruh Kualitas Pelayanan Terhadap Kepuasan Peserta Pensiun Pada PT TASPEN (Persero) Cabang Depok".

\subsection{Perumusan Masalah}

Berdasarkan latar belakang yang telah diuraikan, maka penulis dapat merumuskan permasalahan sebagai berikut :

1. Bagaimana pengaruh Tangible (tangible), Reliability (reliability), Responsiveness (responsiveness), Assurance (assurance) dan Empathy (perhatian) secara parsial dan simultan terhadap kepuasan peserta pensiun pada PT.TASPEN (Persero) Cabang Depok?

2. Variabel manakah yang paling dominan mempengaruhi kepuasan peserta pensiun pada PT.TASPEN (Persero) Cabang Depok?

\subsection{Tujuan Penelitian}

Tujuan penelitian yang dilakukan yaitu :

1. Untuk mengetahui pengaruh Tangible 
(tangible), Reliability (reliability), Responsiveness (responsiveness), Assurance (assurance) dan Empathy (perhatian) secara parsial dan simultan terhadap kepuasan peserta pensiun pada PT.TASPEN (Persero) Cabang Depok?

2. Untuk mengetahui variabel yang paling dominan mempengaruhi kepuasan peserta pensiun pada PT.TASPEN (Persero) Cabang Depok?

\section{TINJAUAN PUSTAKA}

\subsection{Kualitas Pelayanan}

Parasuraman et.al. dalam Mukarom \& Laksana (2016) fakor - faktor yang menentukan kualitas pelayanan adalah SERVQUAL (Service Quality), pendekatan berdasarkan perbandingan dua faktor utama, yaitu persepsi konsumen atas layanan nyata yang mereka terima dan layanan yang sesungguhnya diharapkan. Model ini memiliki lima dimensi yaitu:

1. Tangibles (bukti langsung), yaitu penampilan atau fasilitas fisik, perlengkapan, pegawai, dan alat - alat komunikasi.

2. Reability (reliability), yaitu kemampuan untuk melakukan pelayanan yang telah dijanjikan secara akurat.

3. Responsiveness (responsiveness), kesediaan untuk membantu konsumen dan menyediakan pelayanan dengan cepat.

4. Assurance (assurance), yaitu pengetahuan kesopansantunan para pegawai dan kemampuan untuk menyampaikan kepercayaan dan kerahasiaan.

5. Emphathy (peduli), yaitu kepedulian dan perhatian individual yang diberikan oleh perusahaan kepada konsumen.

\subsection{Kepuasan Konsumen Masyarakat}

Berdasarkan pada keputusan Menteri Pendayagunaan Aparatur Negara: KEP/25/M.PAN/2/2004 (dalam Mukarom \& Laksana, 2016:129) untuk mengukur tingkat kepuasan pelanggan atau masyarakat perlu adanya indeks kepuasan. Indeks kepuasan pelanggan tersebut dikembangkan menjadi 14 unsur yang relevan, valid dan reliabel sebagai unsur minimal yang harus ada. Adapun pengukuran indeks kepuasan pelanggan atau masyarakat tersebut meliputi :

1. Prosedur pelayanan, yaitu kemudahan tahapan-tahapan atau alur pelayanan yang diberikan kepada pelanggan dilihat dari sisi kesederhanaan alur pelayanan.

2. Persyaratan Pelayanan, yaitu persyaratan teknis dan administrasi yang diperlukan untuk mendapatkan pelayanan sesuai dengan jenis pelayanannya.

3. Kejelasan petugas pelayanan, yaitu keberadaan dan kepastian petugas yang memberikan pelayanan (nama, jabatan serta kewenangan dan tanggung jawab).

4. Kedisiplinan petugas pelayanan, yaitu kesungguhan petugas dalam memberikan pelayanan terutama terhadap konsistensi waktu kerja sesuai ketentuan yang berlaku.

5. Tanggung jawab petugas pelayanan, yaitu kejelasan wewenang dan tanggung jawab petugas dalam penyelenggaraan dan penyelesaian pelayanan.

6. Kemampuan petugas pelayanan, yaitu tingkat keahlian dan keterampilan yang dimiliki petugas dalam memberikan atau menyelesaikan pelayanan kepada masyarakat.

7. Kecepatan pelayanan, yaitu target waktu pelayanan yang dapat diselesaikan dalam waktu yang telah ditentukan oleh unit penyelenggara pelayanan.

8. Keadilan mendapatkan pelayanan, yaitu pelaksanaan pelayanan dengan tidak membedakan golongan atau status pelanggan yang dilayani.

9. Kesopanan dan keramahan petugas, yaitu sikap dan perilaku petugas dalam memberikan pelayanan kepada pelanggan secara sopan dan ramah serta saling menghargai dan menghormati.

10. Kewajaran biaya pelayanan, yaitu keterjangkauan masyarakat terhadap besarnya biaya yang ditetapkan oleh unit pelayanan. 
11. Kepastian biaya pelayanan, yaitu kesesuaian antara biaya yang dibayarkan dengan biaya yang telah ditetapkan.

12. Kepastian jadwal pelayanan, yaitu pelaksanaan waktu pelayanan, sesuai dengan ketentuan yang telah ditetapkan.

13. Kenyamanan lingkungan, yaitu kondisi sarana dan prasarana pelayanan yang bersih, rapi, dan teratur sehingga dapat memberikan rasa nyaman kepada penerima pelayanan.

14. Keamanan pelayanan, yaitu terjaminnya tingkat keamanan lingkungan unit penyelenggaraan pelayanan ataupun sarana yang digunakan, sehingga pelanggan merasa tenang untuk mendapatkan pelayanan.

Berdasarkan pengukuran kepuasan pelayanan seperti yang telah dijelaskan diatas, maka instrumen yang akan digunakan dalam penelitian ini hanya yang sesuai dengan objek penelitian meliputi : prosedur pelayanan, persyaratan pelayanan, kecepatan pelayanan, kepastian biaya pelayanan dan kemampuan petugas pelayanan.

\subsection{Definisi Operasional}

Definisi operasional berisi indikatorindikator yang digunakan dalam pertanyaan kuesioner sesuai dengan variabel yang diajukan dalam landasan teori tentang kualitas layananan dan kepuasan konsumen peserta pensiun. Secara rinci tabel definisi operasional disajikan dalam Tabel 1.

\section{Tabel 1. Definisi Operasional}

\begin{tabular}{|c|c|l|}
\hline Variabel & Dimensi & \multicolumn{1}{|c|}{ Indikator } \\
\hline Kualitas & & fasilitas sarana \\
pelayanan & & dan prasarana \\
(Parasurama & Tangible & yang memadai \\
\cline { 3 - 3 } n, et.al. & (Tangible) & informasi \\
(2002) & & persyaratan klim \\
\cline { 3 - 3 } dalam & & lokasi yang \\
Mukarom \& & & strategis \\
\cline { 3 - 3 } Laksana & Reliability & Jenis layanan \\
$(2016)$ & (Reliability) & yang diberikan \\
& & sesuai \\
\hline
\end{tabular}

\begin{tabular}{|c|c|c|}
\hline Variabel & $\overline{\text { Dimensi }}$ & Indikator \\
\hline & & $\begin{array}{l}\text { memberikan } \\
\text { informasi } \\
\text { produk }\end{array}$ \\
\hline & & $\begin{array}{l}\text { melayani sejak } \\
\text { pertama kali } \\
\text { datang }\end{array}$ \\
\hline & \multirow{3}{*}{$\begin{array}{l}\text { Responsivene } \\
\text { ss } \\
\text { (Responsiven } \\
\text { ess) }\end{array}$} & $\begin{array}{l}\text { staf mengetahui } \\
\text { kebutuhan } \\
\text { peserta pensiun }\end{array}$ \\
\hline & & $\begin{array}{l}\text { staf memiliki } \\
\text { pengetahuan } \\
\text { yang cukup } \\
\text { untuk } \\
\text { pertanyaan dan } \\
\text { keluhan peserta } \\
\text { pensiun }\end{array}$ \\
\hline & & $\begin{array}{l}\text { staf melayani } \\
\text { dengan sigap }\end{array}$ \\
\hline & \multirow{3}{*}{$\begin{array}{c}\text { Assurance } \\
\text { (Assurance) }\end{array}$} & $\begin{array}{l}\text { menjamin } \\
\text { kemanan }\end{array}$ \\
\hline & & $\begin{array}{l}\text { pelayanan gratis } \\
\text { tanpa dipungut } \\
\text { biaya }\end{array}$ \\
\hline & & $\begin{array}{l}\text { ketepatan } \\
\text { pembayaran } \\
\text { dengan waktu } \\
\text { yang sesuai } \\
\end{array}$ \\
\hline & \multirow{3}{*}{$\begin{array}{l}\text { Perhatian } \\
\text { (Empathy) }\end{array}$} & $\begin{array}{l}\text { staf menyapa, } \\
\text { mengucapkan } \\
\text { salam dan } \\
\text { berterimakasih }\end{array}$ \\
\hline & & $\begin{array}{l}\text { staf bersikap } \\
\text { ramah dan sopan } \\
\text { dalam melayani }\end{array}$ \\
\hline & & $\begin{array}{l}\text { staf bersimpatik } \\
\text { terhadap } \\
\text { masalah peserta } \\
\text { pensiun }\end{array}$ \\
\hline \multirow{3}{*}{$\begin{array}{c}\text { Kepuasaan } \\
\text { Peserta } \\
\text { (Kepmen } \\
\text { PAN : KEP } \\
\text { / 25 / } \\
\text { M.PAN/2/2 } \\
\text { 004) dalam } \\
\text { Mukarom \& } \\
\text { Laksana }\end{array}$} & $\begin{array}{l}\text { Prosedur } \\
\text { pelayanan }\end{array}$ & $\begin{array}{l}\text { Kemudahan } \\
\text { Tahap } \\
\text { Pelayanan }\end{array}$ \\
\hline & $\begin{array}{c}\text { Persyaratan } \\
\text { pelayanan }\end{array}$ & $\begin{array}{l}\text { Pelayanan yang } \\
\text { sesuai dengan } \\
\text { jenis pelayanan }\end{array}$ \\
\hline & $\begin{array}{l}\text { Kecepatan } \\
\text { pelayanan }\end{array}$ & $\begin{array}{l}\text { Target } \\
\text { pelayanan dapat } \\
\text { diselesaikan }\end{array}$ \\
\hline
\end{tabular}




\begin{tabular}{|c|c|l|}
\hline \hline Variabel & Dimensi & \multicolumn{1}{|c|}{ Indikator } \\
\hline (2016) & & $\begin{array}{l}\text { dalam waktu } \\
\text { yang ditentukan }\end{array}$ \\
\cline { 2 - 3 } & $\begin{array}{c}\text { Kepastian } \\
\text { biaya } \\
\text { pelayanan }\end{array}$ & $\begin{array}{l}\text { kesesuaian } \\
\text { dengan biaya } \\
\text { yang telah } \\
\text { ditetapkan }\end{array}$ \\
\cline { 2 - 3 } & Kemampuan & Ketepatan staf \\
& petugas & dalam \\
& pelayanan & Memberikan \\
& & atau \\
& & menyelesaikan \\
& & pelayanan \\
\hline
\end{tabular}

\subsection{Kerangka Pemikiran}

Kerangka pemikiran merupakan gambaran penulisan secara terstruktur guna menjelaskan alur permasalahan yang sedang di telilti yang disajikan dalam Gambar 1 .

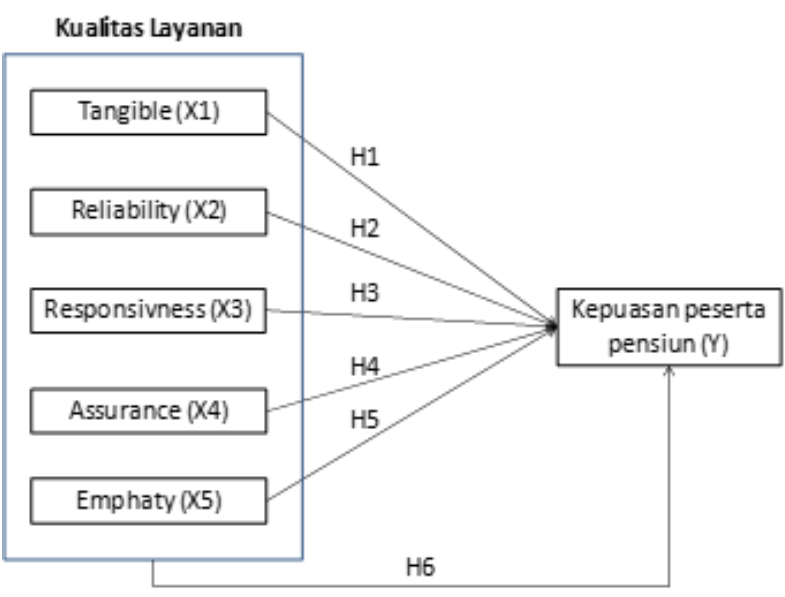

Gambar 1. Kerangka Pemikiran

\subsection{Hipotesis Penelitian}

Hipotesis dalam penelitian ini yaitu :

$\mathrm{H}_{0}$ : Tidak ada pengaruh tangible (X1), reliability (X2), responsivness (X3), assurance (X4) dan emphaty (X5) baik secara parsial maupun simultan terhadap kepuasan peserta pensiun (Y) pada PT.Taspen (persero) Cabang Depok.

$\mathrm{H}_{1}-\mathrm{H}_{5}$ : Ada pengaruh tangible (X1), reliability $(\mathrm{X} 2)$, responsivness $(\mathrm{X} 3)$, assurance (X4) dan emphaty (X5) secara parsial terhadap kepuasan peserta pensiun (Y) pada PT.Taspen (persero) Cabang Depok.
$\mathrm{H}_{6}$ : Ada pengaruh tangible (X1), reliability $(\mathrm{X} 2)$, responsivness $(\mathrm{X} 3)$, assurance (X4) dan emphaty (X5) secara simultan terhadap kepuasan peserta pensiun (Y) pada PT.Taspen (persero) Cabang Depok.

\section{METODE PENELITIAN}

\subsection{Jenis Penelitian}

Jenis yang digunakan dalam penelitian ini adalah penelitian kausalitas dengan pendekatan kuantitatif. Penelitian kausalitas yang bertujuan untuk menyelidiki hubungan sebab-akibat, yaitu untuk mengetahui variabel independen (variabel yang mempengaruhi) dan variabel dependen (variabel yang dipengaruhi). (Sugiyono, 2011:37). Penelitian ini bersifat kuantitatif, yaitu penelitian yang lebih berdasarkan pada data yang dapat dihitung untuk menghasilkan satu penafsiran.

\subsection{Variabel Penelitian}

Variabel dependen penelitian ini yaitu kepuasan peserta pensiun (Y). Variabel independen penelitian ini adalah kualitas pelayanan sebagai variabel bebas yang terdiri dari: Tangible $\left(\mathrm{X}_{1}\right)$, Reliability $\left(\mathrm{X}_{2}\right)$, Responsiveness $\left(\mathrm{X}_{3}\right)$, Assurance $\left(\mathrm{X}_{4}\right)$ dan Empathy $\left(\mathrm{X}_{5}\right)$.

\subsection{Lokasi dan Waktu Penelitian}

Lokasi yang dijadikan tempat untuk penelitian adalah PT Taspen (Persero) Cabang Depok berlokasikan di Jl. Raya Kalimulya No.99 Kel. Kalimulya Kec. Cilodong Kota Depok. Waktu penelitian dilakukan selama 3 bulan (Mei 2017 - Agustus 2017).

\subsection{Populasi dan Sampel}

Populasi adalah keseluruhan jumlah yang terdiri atas objek yang mempunyai karakteristik dan kualitas tertentu yang ditetapkan oleh peneliti untuk diteliti dan kemudian ditarik kesimpulannya (Sujarweni, 2015:80). Populasi dari penelitian ini adalah peserta pensiun PT Taspen (Persero) Cabang Depok sebanyak 23.258 orang. Sampel adalah bagian dari 
sejumlah karakteristik yang dimiliki oleh populasi yang digunakan untuk penelitian (Sujarweni,2015:81).

Metode pengambilan sampling yang digunakan dalam penelitian ini adalah pengambilan sampel menggunakan rumus slovin :

$$
n=\frac{N}{1+\left(N \times e^{2}\right)}=\frac{23.258}{1+23.258(0,1)^{2}}=99,97
$$

Dibulatkan menjadi 100 responden dimana $\mathrm{n}$ adalah ukuran sampel, $\mathrm{N}$ adalah populasi dan $\mathrm{e}$ adalah kelonggaran ketidakterikatan karena kesalahan pengambilan sampel yang masih diinginkan.

\subsection{Teknik Pengumpulan Data}

Teknik pengumpulan data yang digunakan dalam penelitian ini menggunakan kuesioner yang digunakan untuk memperoleh data dari responden dengan cara menyebarkan kuesioner kepada responden. Responden diminta melakukan penilaian berupa angka tentang pelayanan yang diberikan oleh PT. TASPEN (Persero) Cabang Depok. Skala yang digunakan penulis dalam penelitian ini adalah skala Likert. Skala Likert menurut Sugiyono (2011:93) adalah skala yang digunakan untuk mengukur sikap, pendapat, dan persepsi seseorang atau sekelompok orang tentang fenomena sosial. Dalam penelitian berdasarkan tanggapan responden yang bersangkutan. Skor nilai yaitu (1) sangat tidak setuju, (2) tidak setuju, (3) cukup setuju, (4) setuju, dan (5) sangat setuju.

\subsection{Teknik Analisis Data}

\subsubsection{Uji Kualitas Data}

\subsubsection{Uji Validitas}

Uji validitas digunakan untuk mengetahui sah atau valid tidaknya suatu kuesioner. Uji validitas dilakukan dengan membandingkan nilai $r$ hitung dengan $r$ tabel, jika $r$ hitung $>r$ tabel dan bernilai positif, maka variabel tersebut valid sedangkan jika $r$ hitung $<\mathrm{r}$ tabel, maka variabel tersebut tidak valid (Ghozali, 2011:52-53).

\subsubsection{Uji Realibilitas}

Realibilitas adalah alat untuk mengukur suatu kuesioner yang merupakan sebuah indikator dari variabel atau konstruk Suatu kuesioner dikatakan realibel atau handal jika jawaban responden konsisten atau stabil dari waktu ke waktu. SPSS memberikan fasilitas untuk mengukur realibilitas dengan uji statistik Cronbach Alpha. Suatu konstruk atau variabel dikatakan reliabel jika memberikan nilai Cronbach Alpha > 0,60 (Ghozali, 2011:47-48)

\subsubsection{Uji Asumsi Klasik}

3.6.2.1 Uji Normalitas

Menurut Ghozali (2011:160-163).

Deteksi normalitas dilakukan dengan melihat grafik normal Probability Plot. Dasar pengambilan keputusan nya adalah jika data menyebar disekitar garis diagonal dan mengikuti arah garis diagonal maka model regresi memenuhi asumsi normalitas dan jika data menyebar jauh dari garis diagonal dan atau tidak mengikuti arah garis diagonal maka model regresi tidak memenuhi asumsi normalitas.

\subsubsection{Uji Multikolinieritas}

Suatu model regresi yang bebas multikolinieritas adalah mempunyai nilai tolerance lebih dari 0,10 dan nilai VIF kurang dari 10 (Ghozali, 2011:105-106).

\subsubsection{Uji Heterokedastisitas}

Deteksi Heterokedastisitas dapat dilakukan dengan melihat grafik Scatterplot. Dasar pengambilan keputusannya yaitu jika pola tertentu seperti titik - titik yang membentuk suatu pola tertentu yang teratur (bergelombang, melebar kemudian menyempit) maka telah terjadi Heterokedastisitas dan jika tidak ada pola yang jelas serta titik-titik menyebar di atas dan bawah angka 0 pada sumbu $\mathrm{Y}$ maka tidak terjadi Heterokedastisitas. (Ghozali, 2011:139). 


\subsubsection{Analisis Regresi Berganda}

Analisis yang digunakan untuk mengetahui seberapa besar pengaruh lebih dari satu variabel bebas terhadap satu variabel terikat yaitu:

$Y=a+\beta_{1} X_{1}+\beta_{2} X_{2}+\beta_{3} X_{3}+\beta_{4} X_{4}+$ $\beta_{5} X_{5}+\mathrm{e}$

Dimana $\mathrm{Y}$ adalah kepuasan peserta pensiun, $\quad a$ adalah konstanta, $\left(\beta_{1}, \beta_{2}, \beta_{3}, \beta_{4}, \beta_{5}\right)$ adalah koefisien regresi, $\mathrm{X}_{1}$ adalah tangible, $X_{2}$ adalah Reability, $X_{3}$ adalah Responsiveness, $\mathrm{X}_{4}$ adalah Assurance, $\mathrm{X}_{5}$ adalah Empathy dan e adalah kesalahan estimasi standar (error).

\subsubsection{Uji Hipotesis}

\subsubsection{Uji t}

Kriteria

pengujian

dengan

membandingkan $t$ hitung dan $t$ tabel.

a. $\quad t_{\text {hitung }}<\mathrm{t}_{\text {tabel }}$ maka $\mathrm{H}_{0}$ diterima dan $\mathrm{Ha}$ ditolak, artinya adalah tidak memiliki pengaruh secara parsial antara variabel bebas $\left(\mathrm{X}_{1}, \mathrm{X}_{2}, \mathrm{X}_{3}, \mathrm{X}_{4}, \mathrm{X}_{5}\right)$ terhadap variabel terikat $(\mathrm{Y})$.

b. $t_{\text {hitung }}>\mathrm{t}_{\text {tabel }}$ maka $\mathrm{H}_{0}$ ditolak dan $\mathrm{Ha}$ diterima, artinya memiliki pengaruh antara variabel bebas $\left(\mathrm{X}_{1}, \mathrm{X}_{2}, \mathrm{X}_{3}, \mathrm{X}_{4}, \mathrm{X}_{5}\right)$ terhadap variabel terikat $(\mathrm{Y})$.

Kriteria pengujian dengan menggunakan angka signifikansi :

a. Apabila angka signifikansi $<0,05$ maka $\mathrm{H}_{0}$ ditolak Ha diterima.

b. Apabila angka signifikansi > 0,05 maka $\mathrm{H}_{0}$ diterima dan $\mathrm{H}_{\mathrm{a}}$ ditolak.

\subsubsection{Uji F}

Kriteria pengujian

dengan membandingkan $\mathrm{F}_{\text {hitung }}$ dan $\mathrm{F}_{\text {tabel }}$.

a. Jika nilai $\mathrm{F}_{\text {hitung }}<\mathrm{F}_{\text {tabel }}$, maka $\mathrm{H}_{\mathrm{o}}$ diterima dan $\mathrm{H}_{6}$ ditolak, artinya tidak ada pengaruh yang signifikan antara variabel bebas $\left(\mathrm{X}_{1}\right.$, $\mathrm{X}_{2}, \mathrm{X}_{3}, \mathrm{X}_{4}, \mathrm{X}_{5}$ ) secara simultan terhadap variabel terikat $(\mathrm{Y})$.

b. Jika nilai $\mathrm{F}_{\text {hitung }}>\mathrm{F}_{\text {tabel }}$, maka $\mathrm{H}_{\mathrm{o}}$ ditolak dan $\mathrm{H}_{6}$ diterima, artinya memiliki pengaruh yang signifikan antara variabel bebas $\left(\mathrm{X}_{1}, \mathrm{X}_{2}, \mathrm{X}_{3}, \mathrm{X}_{4}, \mathrm{X}_{5}\right)$ secara simultan terhadap variabel terikat $(\mathrm{Y})$.

Kriteria pengujian berdasarkan probabilitasnya:

a. Apabila probabilitas $<0,05$ maka $\mathrm{H}_{0}$ ditolak dan Ha diterima.

b. Apabila probabilitas $>0,05$ maka $\mathrm{H}_{0}$ diterima dan Ha ditolak.

\subsubsection{Uji Koefisien Determinan}

Nilai $\mathrm{R}^{2}$ yang kecil dapat diartikan bahwa kemampuan menjelaskan variabel-variabel bebas dalam menjelaskan variabel terikat sangat terbatas. Nilai yang mendekati satu berarti variabel bebas memberikan hampir semua informasi yang dibutuhkan untuk memprediksi variasi variabel terkait.

\section{HASIL DAN PEMBAHASAN}

\subsection{Sejarah Singkat PT. TASPEN (Persero) Cabang Depok}

PT.TASPEN (PERSERO) sebagai perusahaan asuransi sosial yang menyelenggarakan program pensiun dan THT bagi pegawai negeri sipil dan BUMN ini didirikan dilatarbelakangi keinginan untuk meningkatkan kesejahteraan Pegawai Negeri dan keluarganya yang dirintis melalui Konferensi Kesejahteraan Pegawai Negeri pada Tanggal 25-26 Juli 1960 di Jakarta. Hasil Konferensi tersebut dituangkan dalam Keputusan Menteri Pertama RI Nomor : 388/MP/1960 tanggal 25 Agustus 1960 yang antara lain perlunya pembentukan assurance sosial bagi Pegawai Negeri dan keluarganya pada saat mengakhiri pengabdiannya kepada Negara. Maka pada tanggal 17 April 1963 melalui Peraturan Pemerintah Nomor : 15 tahun 1963 perusahaan yang mengelola assurance sosial untuk Pegawai Negeri tersebut berubah dengan nama Perusahaan Negara Dana Tabungan dan Asuransi Pegawai Negeri atau PN TASPEN. Kemudian pada tahun 1970 meningkat statusnya Perusahaan Umum berdasarkan Surat Keputusan Menteri Keuangan RI Nomor : 749/MK/IV/11/1970 sehingga menjadi PERUM TASPEN. 
Berdasarkan Keputusan Menteri Keuangan Nomor : 822/KMK.03/1986 tanggal 22 September 1986, Nomor : 702/KMK.03/1987 tanggal 31 Oktober 1987, Nomor : 812/KMK.03/1988 tanggal 23 Agustus 1988, Nomor : 79/KMK.03/1990 tanggal 22 Januari 1990 tentang penugasan PT TASPEN (PERSERO) menyelenggarakan pembayaran pensiun untuk wilayah Bali dan NUSRA, wilayah Sumatra dan Jawa-Madura serta wilayah Indonesia Timur (Kalimantan, Sulawesi, Maluku dan Irian Jaya). Kantor Cabang Depok berawal dari Kantor Cabang Pembantu sejak akhir tahun 2010 dengan mendasari Surat Keputusan Direksi Nomor : SK-38/DIR/2010 dan resmi menjadi Kantor Cabang sejak bulan September 2013 dengan mendasari Peraturan Direksi Nomor : PD20/DIR/2013 tanggal 04 September 2013 dengan jumlah peserta aktif sebanyak 7.715 dan peserta pensiun 23.258. Dengan membawahi satu wilayah kota Depok. Berlokasi di Jl. Raya Kalimulya No. 99 Kel. Kalimulya Kec. Cilodong Kota Depok.

\subsection{Hasil Uji Kualitas Data}

\subsubsection{Uji validitas}

Nilai DF (Degree of Freedom) dengan rumus $\mathrm{df}=\mathrm{n}-2$, dimana $\mathrm{n}$ adalah jumlah sampel dengan demikian df yang digunakan adalah $100-2=98$. Dengan Alpha sebesar 5\% maka menghasilkan $\mathrm{r}$ tabel (uji dua sisi) sebesar 0,1966. Berdasarkan hasil pengolahan data dengan menggunakan program SPSS for Windows versi 23 diperoleh hasil uji validitas dari tiap-tiap pertanyaan yang tampak dalam Tabel 2.
Tabel 2 Hasil Pengujian Validitas

\begin{tabular}{|c|c|c|c|c|c|c|}
\hline No. & Variabel & Indikator & $\begin{array}{c}\mathrm{r} \\
\text { hitung }\end{array}$ & $\begin{array}{c}\mathrm{r} \\
\text { tabel }\end{array}$ & $\begin{array}{c}P \\
\text { Value }\end{array}$ & Keterangan \\
\hline \multirow{3}{*}{1} & \multirow{3}{*}{ Tangible (X1) } & $\mathrm{X} 1.1$ & 0,650 & 0,1966 & 0,000 & Valid \\
\hline & & $\mathrm{X} 1.2$ & 0,569 & 0,1966 & 0,000 & Valid \\
\hline & & $\mathrm{X} 1.3$ & 0,603 & 0,1966 & 0,000 & Valid \\
\hline \multirow{3}{*}{2} & \multirow{3}{*}{ Reliability (X2) } & $\mathrm{X} 2.1$ & 0,739 & 0,1966 & 0,000 & Valid \\
\hline & & $\mathrm{X} 2.2$ & 0,563 & 0,1966 & 0,000 & Valid \\
\hline & & $\mathrm{X} 2.3$ & 0,667 & 0,1966 & 0,000 & Valid \\
\hline \multirow{3}{*}{3} & \multirow{3}{*}{$\begin{array}{l}\text { Responsiveness } \\
\text { (X3) }\end{array}$} & $\mathrm{X} 3.1$ & 0,621 & 0,1966 & 0,000 & Valid \\
\hline & & $\mathrm{X} 3.2$ & 0,669 & 0,1966 & 0,000 & Valid \\
\hline & & $\mathrm{X} 3.3$ & 0,844 & 0,1966 & 0,000 & Valid \\
\hline \multirow{3}{*}{4} & \multirow{3}{*}{ Assurance (X4) } & $\mathrm{X} 4.1$ & 0,824 & 0,1966 & 0,000 & Valid \\
\hline & & $\mathrm{X} 4.2$ & 0,743 & 0,1966 & 0,000 & Valid \\
\hline & & $\mathrm{X} 4.3$ & 0,825 & 0,1966 & 0,000 & Valid \\
\hline \multirow{3}{*}{5} & \multirow{3}{*}{ Emphaty (X5) } & $\mathrm{X} 5.1$ & 0,936 & 0,1966 & 0,000 & Valid \\
\hline & & $\mathrm{X} 5.2$ & 0,936 & 0,1966 & 0,000 & Valid \\
\hline & & $\mathrm{X} 5.3$ & 0,782 & 0,1966 & 0,000 & Valid \\
\hline \multirow{5}{*}{6} & \multirow{5}{*}{$\begin{array}{c}\text { Kepuasan } \\
\text { Peserta (Y) }\end{array}$} & Y1.1 & 0,657 & 0,1966 & 0,000 & Valid \\
\hline & & $\mathrm{Y} 1.2$ & 0,275 & 0,1966 & 0,000 & Valid \\
\hline & & $\mathrm{Y} 1.3$ & 0,424 & 0,1966 & 0,000 & Valid \\
\hline & & $\mathrm{Y} 1.4$ & 0,550 & 0,1966 & 0,000 & Valid \\
\hline & & Y1.5 & 0,755 & 0,1966 & 0,000 & Valid \\
\hline
\end{tabular}

Sumber : Data Primer yang diolah, 2017.

Berdasarkan pengujian pada tabel diatas dapat diketahui bahwa nilai $r_{\text {hitung }}$ dari semua indikator lebih besar dari nilai $r_{\text {tabel }}$ nya. Probabilitas kesalahan (sig) dari tiap-tiap indikator semuanya dibawah 0,05 oleh karena itu dapat disimpulkan bahwa semua pertanyaan pada kuesioner dalam penelitian ini adalah valid.

\subsubsection{Uji Reliabilitas}

Berdasarkan hasil yang diperoleh dari pengujian reliabilitas instrumen penelitian dengan menggunakan SPSS menunjukkan masing-masing variabel diperoleh nilai Cronbach Alpha > 0,60 maka dapat disimpulkan bahwa intrumen penelitian tersebut dinyatakan reliabel. Perhitungan nilai koefisien reliabilitas untuk instrumen penelitian yang digunakan diperoleh hasilnya dalam Tabel 3.

Tabel 3. Hasil Pengujian Reliabilitas

\begin{tabular}{|l|c|c|c|}
\hline \multicolumn{1}{|c|}{ Variabel } & $\begin{array}{c}\text { Cronbach's } \\
\text { Alpha }\end{array}$ & Alpha & Keterangan \\
\hline Tangible (X1) & 0,763 & 0,60 & Reliabel \\
\hline Reliability (X2) & 0,802 & 0,60 & Reliabel \\
\hline Responsiveness (X3) & 0,840 & 0,60 & Reliabel \\
\hline Assurance (X4) & 0,896 & 0,60 & Reliabel \\
\hline Emphaty (X5) & 0,942 & 0,60 & Reliabel \\
\hline Kepuasan Peserta (Y) & 0,756 & 0,60 & Reliabel \\
\hline
\end{tabular}

Sumber : Data Primer yang diolah, 2017 


\subsection{Hasil Uji Asumsi Klasik}

\subsubsection{Uji Normalitas}

Uji normalitas menunjukkan data sesungguhnya mengikuti garis yang diagonal yang menunjukkan terjadi normalitas data sesuai dengan hasil output SPSS for Windows ditunjukkan dalam Gambar 2.

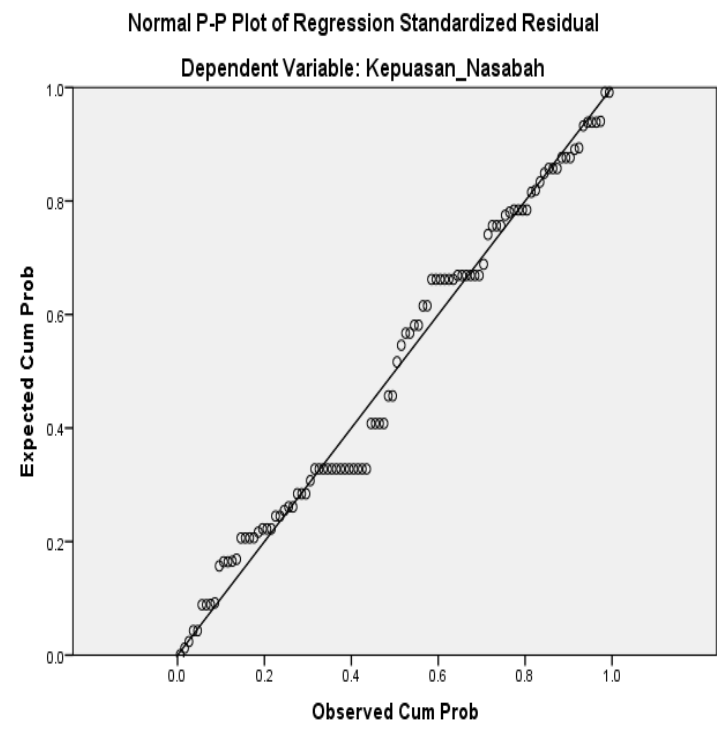

Gambar 2. Grafik Hasil Uji Normalitas

\subsubsection{Uji Multikolinearitas}

Dalam penelitian ini tidak terjadi gejala multikolinearitas dilihat dari nilai tolerance yang lebih besar dari $\alpha=0,05$ dan Variance Inflation Factor (VIF) < 10. Hasil uji multikolinearitas dapat dilihat pada table 4 .

\section{Tabel 4. Hasil Pengujian Multikolinearitas}

\begin{tabular}{|l|c|c|l|}
\hline \multirow{2}{*}{ Model } & \multicolumn{2}{|c|}{$\begin{array}{c}\text { Collinearity } \\
\text { Statistics }\end{array}$} & \multirow{2}{*}{ Keterangan } \\
\cline { 2 - 3 } & Tolerance & VIF & \\
\hline Tangible (X1) & 0,495 & 2,018 & $\begin{array}{l}\text { Tidak Terjadi } \\
\text { Multikolinearitas }\end{array}$ \\
\hline $\begin{array}{l}\text { Reliability } \\
\text { (X2) }\end{array}$ & 0,647 & 1,546 & $\begin{array}{l}\text { Tidak Terjadi } \\
\text { Multikolinearitas }\end{array}$ \\
\hline $\begin{array}{l}\text { Responsivene } \\
\text { ss (X3) }\end{array}$ & 0,461 & 2,168 & $\begin{array}{l}\text { Tidak Terjadi } \\
\text { Multikolinearitas }\end{array}$ \\
\hline $\begin{array}{l}\text { Assurance } \\
\text { (X4) }\end{array}$ & 0,528 & 1,892 & $\begin{array}{l}\text { Tidak Terjadi } \\
\text { Multikolinearitas }\end{array}$ \\
\hline $\begin{array}{l}\text { Emphaty } \\
\text { (X5) }\end{array}$ & 0,465 & 2,150 & $\begin{array}{l}\text { Tidak Terjadi } \\
\text { Multikolinearitas }\end{array}$ \\
\hline
\end{tabular}

Sumber : Data Primer yang diolah, 2017

\subsubsection{Uji Heteroskedastisitas}

Hasil pengujian heteroskesdastisitas menunjukkan bahwa titik-titik tidak membentuk pola tertentu dan titik-titik menyebar di atas dan di bawah angka 0 pada sumbu Y (Gambar ). Hal ini menunjukkan bahwa model regresi tidak terjadi heteroskedastisitas ditunjukan pada Gambar 3.

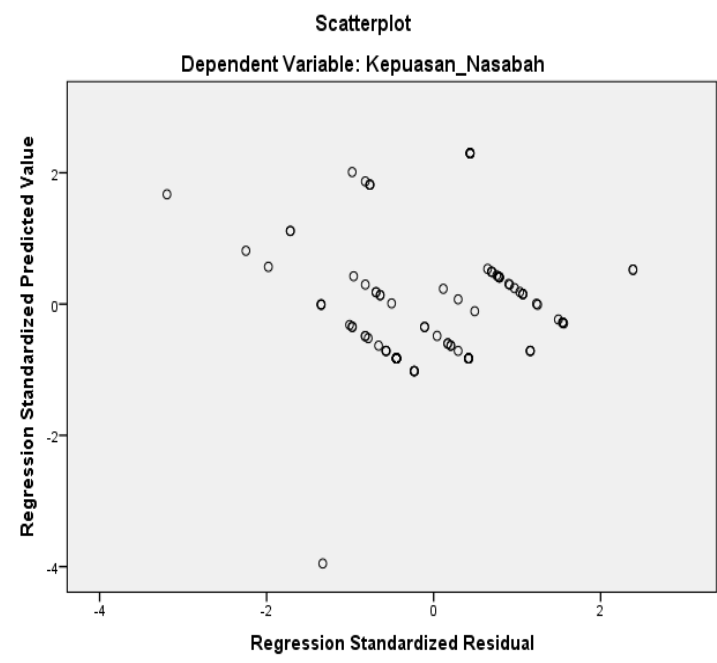

Gambar 3. P-plot Uji Heteroskedastisitas

\subsection{Analisis Regresi Linear Berganda}

Analisis regresi linear berganda digunakan dalam penelitian ini dengan tujuan untuk mengetahui ada tidaknya pengaruh variabel independen terhadap variabel dependen. Ringkasan hasil pengolahan data dengan menggunakan program SPSS for Windows versi 23 disajikan dalam Tabel 5.

Tabel 5. Hasil Uji Regresi Linear Berganda, Uji t, Signifikansi dan Kolinieritas

\begin{tabular}{|c|c|c|c|c|c|c|c|}
\hline \multirow[t]{2}{*}{ Model } & \multicolumn{2}{|c|}{$\begin{array}{c}\text { Unstandardized } \\
\text { Coefficients }\end{array}$} & \multirow{2}{*}{$\begin{array}{c}\begin{array}{c}\text { Standardized } \\
\text { Coefficients }\end{array} \\
\text { Beta }\end{array}$} & \multirow[t]{2}{*}{ t } & \multirow[t]{2}{*}{ Sig. } & \multicolumn{2}{|c|}{$\begin{array}{c}\text { Collinearity } \\
\text { Statistics } \\
\end{array}$} \\
\hline & B & Std. Error & & & & Tolerance & VIF \\
\hline (Constant) & 4.603 & 1.581 & & 2.911 & .004 & & \\
\hline Tangible & .247 & .122 & .197 & 2.030 & .045 & .495 & 2.018 \\
\hline Reliability & .305 & .121 & .215 & 2.523 & .013 & .647 & 1.546 \\
\hline Responsiveness & .448 & .156 & .290 & 2.882 & .005 & .461 & 2.168 \\
\hline Assurance & .144 & .116 & .117 & 1.243 & .217 & .528 & 1.892 \\
\hline Emphaty & .182 & .137 & .134 & 1.331 & .186 & .465 & 2.150 \\
\hline
\end{tabular}

Sumber : Hasil analisis data 2017

Berdasarkan hasil Tabel 5, maka persamaan regresinya adalah sebagai berikut :

$$
\begin{gathered}
Y=4,603+0,247 X_{1}+0,305 X_{2}+0,448 X_{3}+ \\
0,144 X_{4}+0,182 X_{5}+e
\end{gathered}
$$

Dimana $\mathrm{X}_{1}$ adalah tangible, $\mathrm{X}_{2}$ adalah reliability, $\mathrm{X}_{3}$ adalah responsiveness, $\mathrm{X}_{4}$ 
adalah assurance, $\mathrm{X}_{5}$ adalah emphaty dan $\mathrm{e}$ adalah standard error.

Persamaan regresi berganda tersebut dijelaskan sebagai berikut :

1. Nilai konstanta sebesar 4,603 berarti bahwa jika variabel Tangible, Reliability, Daya Tangkap, Assurance dan Emphaty sama dengan nol, maka Kepuasan Peserta Pensiun adalah sebesar 4,603.

2. Variabel Tangible $\left(\mathrm{X}_{1}\right)$ memiliki koefisien sebesar 0,247. Ini menunjukkan bahwa variabel Tangible meningkat 1 satuan maka kepuasan peserta pensiun akan meningkat 0,247 satuan.

3. Variabel Reliability $\left(\mathrm{X}_{2}\right)$ memiliki koefisien sebesar 0,305. Ini menunjukkan bahwa variabel Reliability meningkat 1 satuan maka kepuasan peserta pensiun akan meningkat 0,305 satuan

4. Variabel Responsiveness $\left(\mathrm{X}_{3}\right)$ memiliki koefisien sebesar 0,448. Ini menunjukkan bahwa variabel Daya Tangkap meningkat 1 satuan maka kepuasan peserta pensiun akan meningkat 0,448 satuan.

5. Variabel Assurance $\left(\mathrm{X}_{4}\right)$ memiliki koefisien sebesar 0,144. Ini menunjukkan bahwa variabel Assurance meningkat 1 satuan maka kepuasan peserta pensiun akan meningkat 0,144 satuan.

6. Variabel Emphaty $\left(\mathrm{X}_{5}\right)$ memiliki koefisien sebesar 0,182. Ini menunjukkan bahwa variabel Emphaty meningkat 1 satuan maka kepuasan peserta pensiun akan meningkat 0,182 satuan.

\subsection{Uji Hipotesis}

\subsubsection{Uji t}

Penentuan DF $=(\mathrm{n}-1-\mathrm{k})=100-5-1=$ 94 dan diperoleh $t_{\text {tabel }}$ sebesar 1,986 (sig 0,05). Hasil Uji $t$ disajikan dalam Tabel 5 menunjukan bahwa dari 5 variabel kualitas layanan dalam penelitian ini hanya terdapat 3 variabel yang memiliki pengaruh signifikan terhadap variabel kepuasan peserta pensiun. Secara rinci penjelasan uji hipotesis secara parsial yang dikenal dengan uji $\mathrm{t}$ sebagai berikut :
1. Variabel Tangible (X1) memiliki nilai $\mathrm{t}_{\text {hitung }}=2,030$ dengan tingkat signifikansi 0,045 . Dengan menggunakan batas signifikansi 0,05 , nilai signifikansi tersebut berada diatas taraf $5 \%$ dan $\mathrm{t}_{\text {hitung }}$ sebesar 2,030 $>t_{\text {tabel }}$ sebesar 1,986 yang berarti $\mathrm{H}_{\mathrm{o}}$ ditolak dan $\mathrm{H}_{1}$ diterima. Maka dapat disimpulkan bahwa variabel Tangible berpengaruh dan signifikan terhadap Kepuasan Peserta.

2. Variabel Reliability (X2) memiliki nilai $\mathrm{t}_{\text {hitung }}=2,523$ dengan tingkat signifikansi 0,013 . Dengan menggunakan batas signifikansi 0,05 , nilai signifikansi tersebut berada diatas taraf $5 \%$ dan $\mathrm{t}_{\text {hitung }}$ sebesar $2.523>\mathrm{t}_{\text {tabel }}$ sebesar 1,986 yang berarti $\mathrm{H}_{\mathrm{o}}$ ditolak dan $\mathrm{H}_{2}$ diterima. Maka dapat disimpulkan bahwa variabel Reliability berpengaruh dan signifikan terhadap Kepuasan Peserta.

3. Variabel Responsiveness (X3) memiliki nilai $t_{\text {hitung }}=2.882$ dengan tingkat signifikansi 0,005. Dengan menggunakan batas signifikansi 0,05 , nilai signifikansi tersebut berada diatas taraf $5 \%$ dan $\mathrm{t}_{\text {hitung }}$ sebesar $2.882>\mathrm{t}_{\text {tabel }}$ sebesar 1,986 yang berarti $\mathrm{H}_{\mathrm{o}}$ ditolak dan $\mathrm{H}_{3}$ diterima. Maka dapat disimpulkan bahwa variabel Responsiveness berpengaruh dan signifikan terhadap Kepuasan Peserta.

4. Variabel Assurance (X4) memiliki nilai $\mathrm{t}_{\text {hitung }}=1,243$ dengan tingkat signifikansi 0,217 . Dengan menggunakan batas signifikansi $\quad 0,05$, nilai signifikansi tersebut berada diatas taraf $5 \%$ dan $t_{\text {hitung }}$ sebesar $1.243<\mathrm{t}_{\text {tabel }}$ sebesar 1,986 yang berarti $\mathrm{H}_{\mathrm{o}}$ diterima dan $\mathrm{H}_{4}$ ditolak. Maka dapat disimpulkan bahwa variabel assurance tidak berpengaruh signifikan terhadap Kepuasan Peserta.

5. Variabel Emphaty (X5) memiliki nilai $\mathrm{t}_{\text {hitung }}=1.331$ dengan tingkat signifikansi 0,186 . Dengan menggunakan batas signifikansi 0,05 , nilai signifikansi tersebut berada diatas taraf $5 \%$ dan $\mathrm{t}_{\text {hitung }}$ sebesar $1.331<\mathrm{t}_{\text {tabel }}$ sebesar 1,986 yang berarti $\mathrm{H}_{\mathrm{o}}$ diterima dan $\mathrm{H}_{5}$ ditolak. Maka dapat disimpulkan bahwa variabel 
Emphaty tidak berpengaruh signifikan terhadap Kepuasan Peserta.

\subsubsection{Uji F}

Perhitungan df $1=\mathrm{k}-1=6-1=5$ dan df2 $=\mathrm{n}-\mathrm{k}=100-6=94$ sehingga nilai $\mathrm{F}_{\text {tabel }}$ sebesar 2,31 pada signifikansi 0,05. Hasil perhitungan statistik menunjukkan nilai $\mathrm{F}_{\text {hitung }}$ $=23,934>\mathrm{F}_{\text {tabel }}=2,31$ dan signifikansi sebesar $0,000<0,05$. Hal ini menyatakan bahwa $\mathrm{H}_{0}$ ditolak dan $\mathrm{H}_{6}$ diterima yang menunjukkan kepuasan peserta pensiun dipengaruhi secara simultan dan signifikan oleh variabel Tangible, Reliability, Responsiveness, Assurance dan Emphaty. Hasil perhitungan uji $\mathrm{F}$ dapat dilihat pada Tabel 6.

Tabel 6. Hasil Uji F

\begin{tabular}{|l|r|r|r|r|r|}
\hline \multicolumn{1}{|c|}{ Model } & \multicolumn{1}{c|}{$\begin{array}{c}\text { Sum of } \\
\text { Squares }\end{array}$} & \multicolumn{1}{c|}{ df } & $\begin{array}{c}\text { Mean } \\
\text { Square }\end{array}$ & F & Sig. \\
\hline Regression & 160.466 & 5 & 32.093 & 23.934 & .000 \\
\hline Residual & 126.044 & 94 & 1.341 & & \\
\hline Total & 286.510 & 99 & & & \\
\hline
\end{tabular}

Sumber : Hasil olahan data 2017

\section{KESIMPULAN DAN SARAN}

\subsection{Kesimpulan}

Kesimpulan yang diperoleh dari penelitian ini adalah :

1. Variabel Tangible, Reliability dan Responsiveness secara parsial memiliki pengaruh yang signifikan terhadap Kepuasan Peserta Pensiun sedangkan variabel Assurance dan Emphaty secara parsial tidak berpengaruh signifikan terhadap kepuasan peserta pensiun.

2. Variabel Tangible, Reliability, Responsiveness, Assurance dan Emphaty secara simultan memiliki pengaruh yang signifikan terhadap Kepuasan Peserta Pensiun.

3. Dari ke lima faktor dalam penelitian ini, variabel Responsiveness $\left(\mathrm{X}_{3}\right)$ merupakan variabel yang paling berpengaruh terhadap tingkat Kepuasan Peserta Pensiun pada PT Taspen (Persero) Cabang Depok dengan koefisien Responsiveness sebesar 0,448 dan signifikan dengan nilai $t_{\text {hitung }}=2.882$ pada $\alpha=0,005<5 \%$.

4. Variabel independen dalam penelitian ini memiliki pengaruh sebesar 53,7\% terhadap Kepuasan Peserta Pensiun pada PT Taspen (Persero) Cabang Depok, sedangkan sisanya 46,3\% dijelaskan oleh faktor lain di luar penelitian.

\subsection{Saran}

Saran yang diberikan dalam penelitian ini yaitu :

1. Penelitian ini masih belum bisa mengungkapkan secara keseluruhan faktor-faktor yang mempengaruhi Kepuasan Peserta Pensiun. Oleh karena itu perlu adanya penelitian lebih lanjut.

2. Variabel Tangible, Reliability dan Responsiveness perlu dipertahankan karena sudah dapat menunjukan kepuasan peserta.

3. Variabel Assurance dan Emphaty tidak berpengaruh terhadap kepuasan peserta. Hal ini menjadi pertimbangan oleh PT Taspen (Persero) Cabang Depok untuk memperbaiki kualitas layanan kedua variabel ini agar kedepannya kepuasan peserta pensiun dapat lebih meningkat.

\section{DAFTAR PUSTAKA}

Ghozali, Imam. 2011. Aplikasi Analisis Multivariate Dengan Program IBM SPSS 19.Ed. 5.Semarang: Badan Penerbit Universitas Diponegoro.

Herawati, Vida. 2013. Pengaruh Kualitas Pelayanan Kartu Anjungan Tunai Mandiri (ATM) Terhadap Kepuasan Nasabah Pada Bank Mandiri Cabang Jakarta Wisma Tugu.

Mawardi, Khairul Basri. 2013. Pengaruh Kualitas Pelayanan Terhadap Kepuasan Pasien klinik Sapta Mitra Bekasi Timur.

Misbahudin. 2013. Pengaruh Kualitas Pelayanan Akademik Terhadap Kepuasan Mahasiswa STIE Dewantara Cibinong.

Mukarom, Z. dan Laksana, M.W. 2016. Membangun Kinerja Pelayanan Publik 
Menuju Clean Goverment and Good

Governance. Jawa Barat: CV. Pustaka Setia.

Pedoman Umum Penyusunan Indeks

Kepuasan Masyarakat Unit Pelayanan

Instansi Pemerintah. 2004. Keputusan

Menteri Pendayagunaan Aparatur Negara

Nomor: $\quad$ KEP/25/M.PAN/2/2004.

Kementerian Pendayagunaan Aparatur

Negara Republik Indonesia.

Sangdji, E.M dan Sopiah. 2013. Perilaku

Konsumen Pendekatan Praktis Disertai

Himpunan Jurnal Penelitian. Yogyakarta :

CV. Andi Offset.

Sugiono.2011. Metode Penelitian Kuantitatif,

Kualitatif, Dan R\&D. Bandung:

CV.ALFABETA.

Sujarweni, V.W. 2015. Metodologi Penelitian

Bisnis dan Ekonomi. Yogyakarta: Pustaka

Baru Press. 